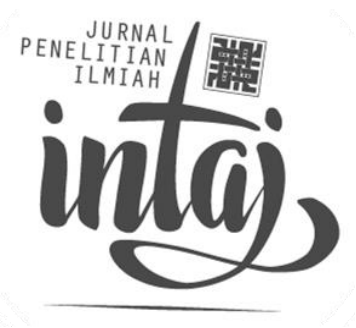

\title{
IMPLEMENTASI KURIKULUM BAHASA ARAB DI PTKIS
}

\author{
Abdurrahman (gusdur@alqolam.ac.id) \\ Institut Agama Islam (IAI) Al-Qolam Malang
}

(Received: Agustus 2018 / Revised: Agustus 2018 / Accepted: September 2018)

\begin{abstract}
Arabic language education has become one of the subjects in all programs of faculties in Islamic Universities (PTKIS), especially in 154 Universities under the supervision of the fourth Coordinator for Islamic Universities, (Kopertais IV). However, the phenomenon of communicative foreign language learning (PBAK) according to the KTSPT 2009 was not directed at achieving the five competencies of the Kepmendiknas Regulation No. 045 (2002), for the clustering of certain subjects in the independent subjects. This leads to reduce graduate degree competence. This paper was presented in particular in the future approaches to curriculum building through the competency based the Indonesian Qualifications Framework (KBK KKNI) in accordance with the Presidential decree No. 8 (2012) by setting the communicative scope in teaching Arabic as an approach to achieve all five competencies together. The first possible plan for this purpose is to make use of the Language Center (LC) in two plans. First reforming the status of the language center, and secondly delegating subjects from college faculties to language center.
\end{abstract}

Keywords: Arabic, PBAK, KBK, KKNI, LC 


\section{PENDAHULUAN}

Acuan utama bagi upaya meningkatkan peran pendidikan tinggi di Indonesia untuk memperkuat daya saing bangsa dalam menghadapi persaingan global, adalah kenyataan bahwa Pendidikan Tinggi di Indonesia masih belum mampu bersaing dengan Pendidikan Tinggi Asia apalagi Dunia. Bahkan menurut laporan The Academic Ranking of World Universities (ARWU) tahun 2018, yang dilansir oleh Center for World-Class Universities of Shanghai Jiao Tong University (CWCU) ${ }^{1}$, belum satupun Universitas di Indonesia yang masuk ranking 1000 Perguruan Tinggi terbaik Dunia. Demikian juga laporan dari The Times Higher Education World University Rankings ${ }^{2}$, tidak ada Perguruan Tinggi Indonesia yang masuk 500 peringkat dunia, bahkan pada 100 ranking terbaik Asia, ${ }^{3}$ kecuali pemeringkatan yang didasarkan pada popularitas, kegiatan publikasi ilmiah dan frekwensi visitasi pada web perguruan tinggi bersangkutan. Sebagaimana dilansir oleh 4 International Colleges \& Universities (4ICU), yang memasukkan tiga PT Indonesia dalam 200 besar peringkat Asia, yaitu UGM (43), dan UI (107). Universitas Sebelas Maret (120), Universitas Diponegoro (171), IPB (175), UB (181), Universitas Airlangga (184), dan UNY (190), semuanya adalah Perguruan Tinggi Umum (PTU) ${ }^{4}$.

\footnotetext{
${ }^{1}$ Center for World -Class Universitas Shanghai Jiao Tong University, "Academic Ranking of World Universities 2018", http://WwW.shanghairanking.com/ARWU2018.html, (diakses pada 7 Oktober 2018). The Academic Ranking of World Universities(ARWU) adalah laporan peringkat akademik Perguruan Tinggi Dunia yang dilakukan oleh para peneliti di Pusat Universitas kelas Dunia (Center for World-Class Universitas Shanghai Jiao Tong University, CWCU).

2 The Times Higher Education World University Rankings adalah lembaga peringkat Perguruan Tinggi kelas Dunia yang didukung oleh Thomson Reuters. Diklaim sebagai laporan yang diterima luas karena manyajikan analisa yang komprehensip dan seimbang. Kunjungi; https://www.timeshighereducation.com/world-university-rankings/2018/world-ranking. (diakses pada 7 Oktober 2018)

3 The Times Higher Education World University Rankings, "Asia University Ranking 2018", https://www.timeshighereducation.com/world-university-rankings/2018/regional-ranking. (diakses pada 7 Oktober 2018)

42018 Asian University Ranking, "2018 Asian University Ranking", https://www.4icu.org/topuniversities-asia/(diakses pada 7 Oktober 2018).
} 
Di Indonesia sendiri, Perguruan Tinggi Keagamaan Islam (PTKI) masih kalah saing dengan perguruan tinggi umum (PTU). Menurut laporan 4ICU tahun 2018, peringkat tertinggi PTAI adalah ranking 16, yang ditempati oleh Universitas Islam Indonesia ${ }^{5}$. Sementara laporan versi Webometric 2013, peringkat tertinggi adalah ranking 29 yang ditempati PT yang sama ${ }^{6}$. Diantara faktor ketertinggalan PTAI dari PTU adalah lemahnya kompetensi Bahasa Asing, minimal bahasa asing populer; Bahasa Arab dan Bahasa Inggris 7 .Untuk itu, pemerintah dalam hal ini Kemenag RI, dalam beberapa tahun ini menggiatkan program kelas internasional (International Class Program, ICP) di beberapa PTKIN, yang mensyaratkan penguasaan bahasa asing.

Dalam rangka meningkatkan kualitas Perguruan Tinggi Agama Islam (PTAI) terutama swasta, Kordinatorat Perguruan Tinggi Agama Islam Swasta Wilayah IV (Kopertais IV) Surabaya telah mencanangkan pengembangan kurikulum yang masih berlaku, Kurikulum Tingkat Satuan Pendidikan Tinggi (KTSPT) tahun 2009. Racangan pengembangan yang dimaksud adalah untuk merespon kebijakan paling anyar terkait hal ini, yaitu Peraturan Presiden Republik Indonesia nomor 8 tahun 2012 tentang Kerangka Kualifikasi Nasional Indonesia (KKNI). Regulasi ini bertujuan untuk menyandingkan, menyeratakan dan mensinergikan sektor pendidikan, baik formal maupun nonformal dalam rangka pemberian pengakuan dan penghargaan terhadap kompetensi profesi lulusan. Rancangan KKNI ini didasarkan pada kemampuan lembaga pendidikan (supply push) yang khas Indonesia dan menyelaraskannya dengan masyarakat pengguna (demand pull) secara global, sehingga merujuk dan mempertimbangkan kerangka kualifikasi yang

\footnotetext{
${ }^{5}$ http://www.4icu.org/id/ (diakses pada 7 Oktober 2018). UIN Maliki Malang (30), UIN Riau (37), UIN Jakarta (38), UIN Surabaya (43), UIN Makasar (58), UIN Bandung (65), UIN aceh (118), UIN Jambi (134), UIN Lampung (156), dan UIN Padang (230).

${ }^{6}$ Sebagaimana 4ICU, Webometrics Ranking of World Universities adalah laporan pemeringkatan berdasarkan kegiatan ilmiah cybermetrics yang mengangkat popularitas PT bersangkutan lewat web. Organisasi ini berpusat di Spanyol dengan laboratorium berpusat di Gedung Centro de Ciencias Humanas Sociales (CCHS). Kunjungi: Webometrics, "About Us", http://www.webometrics.info/en/About Us, (diakses pada 7 Oktober 2018)

7 Mudjia Rahardjo, "Tantangan Sarjana PTAI menyongsong Priode Respiritualisasi Global', Orasi IImiah, disampaikan pada Rapat Senat Terbuka Wisuda TA. 2013/2014 STAI Al-Qolam Gondanglegi, tanggal 7 Desember 2013 (Gondanglegi: STAI Al-Qolam, 2013)
} 
digunakan beberapa Negara lain, seperti European Qualification Framework (EQF) dan Australian Qualification Framework $(\mathrm{AQF})^{8}$. Salah satu kelanjutan dari regulasi ini adalh terbitnya Peraturan Menteri Pendidikan dan Kebudayaan RI nomor 81 tahun 2014 tentang Ijazah, Sertifikat Kompetensi, dan Sertifikat Profesi Pendidikan Tinggi, yang bahkan di dalamnya diatur penerbitan Surat Keterangan Pendamping Ijazah (SKPI) sebagai legal formal dari penyelarasan kualifikasi lulusan Perguruan Tinggi. ${ }^{9}$

Untuk menyikapi regulasi yang secara langsung harus menjadi salah satu pijakan pengembangan kurikulum, termasuk kurikulum di Perguruan Tinggi Islam kedepan, maka Kopertais IV mengadakan Lokakarya Kurikulum KBK - KKNI, yang ditempatkan di Hotel Utami Sidoarjo pada tanggal 11-13 November 2013 silam. Kegiatan pengembangan kurikulum tersebut diikuti oleh 50 PTAIS di bawah Kopertais IV dengan mewakili 18 Prodi. Namun sebagaimana tertulis dalam Notelensi hasil lokakarya, Tim Pengembang Kopertais IV menyatakan bahwa hasil lokakarya masih berupa draft yang masih sangat mentah, sehingga masih harus dikembangkan lebih lanjut pada masing-masing PTAIS ${ }^{10}$. Sehingga secara praktis, seluruh PTAIS di bawah Kopertais IV masih menggunakan Kurikulum Tingkat Satuan Pendidikan Tinggi (KTSPT) tahun 2009, sebelum merampungkan rumusan

\footnotetext{
${ }^{8}$ Rujukan terhadap beberapa kerangka kualifikasi beberapa Negara hanya sebatas pertimbangan dan mungkin ada beberapa hal yang dapat diadopsi dan kemudian tetap harus disesuaikan dengan kondisi di Indonesia. Dalam hal penjenjangan misalnya, Indonesian Qualification Framework (IQF) dengan 9 jenjang, lebih tinggi dari Hongkong (7 jenjang) dan Eropa (8 jenjang), dan lebih rendah dari Selandia Baru (10 jenjang) dan Australia (11 jenjang). Di Australia, AQF menerapkan pemisahan pendidikan vokasi (vocational education and training, VET) dari pendidikan tinggi (Higher Education Sector), yang hal ini tidak boleh diaplikasikan di Indonesia karena melanggar UU Sisdiknas nomor 20 tahun 2003. Lihat: Fauzi Kromosudiro, "Konsep Dasar KKNI", www.fauziep.com/konsep-dasar-kkni/ (diakses pada 7 Oktober 2018)

9 Peraturan Menteri Pendidikan dan Kebudayaan RI nomor 81 tahun 2014, ditetapkan pada tanggal 20 Agustus 2014 oleh Muhammad Nuh.

${ }^{10}$ Abdul Muhid, 'Hasil Lokakarya Kurikulum KBK berbasis KKNI Kopertais IV Surabaya Tahun 2013', Notulensi, (Surabaya: Tim Pengembang Kopertais IV, 2013). Sebagai kelanjutan dari Lokakarya tersebutm Kopertais Wilayah IV Surabaya mengadakan Workshop Penulisan Buku Ajar pada tanggal 18 - 20 November 2014 yang lalu di Hotel Empire Palace Surabaya.
} 
pengembangan kurikulum pada masing-masing lembaga sebagaimana diamanatkan melalui forum lokakarya tersebut.

Dari rumusan Dokumen KTSPT 2009 tersebut, menurut penulis, dapat diidentifikasi secara kasar, bagaimana kondisi riil pembelajaran Bahasa Asing pada masing-masing PTAIS. Berangkat dari Dokumen inilah, penulis hanya akan fokus pada pertanyaan bagaimana solusi konstruksi Pembelajaran Bahasa Asing yang tepat dalam rumusan Kurikulum KBK berbasis KKNI?. Untuk mendeskripsikan konstruksi yang dimaksud, tulisan ini didasarkan pada Dokumen KTSPT 2009 pada Prodi Pendidikan Agama Islam (PAI). Setidaknya tiga alasan yang dapat diajukan dalam hal ini; pertama, Prodi PAI merupakan Prodi terbanyak di Kopertais IV Surabaya saat ini, ${ }^{11}$ kedua, STAI Al-Qolam - lembaga tempat penulis mengabdi saat ini - belum memiliki Prodi Pendidikan Bahasa Arab, dan ketiga, hal ini untuk menegaskan bahwa tulisan ini adalah gagasan secara filosofis pada pembelajaran Bahasa Arab pada Prodi non Pendidikan Bahasa Arab.

\section{MENYOAL PEMBELAJARAN BAHASA ASING PADA KTSPT TAHUN 2009}

Kurikulum Tingkat Satuan Pendidikan Tinggi (KTSPT) tahun 2009 dirumuskan oleh Kopertais IV melalui 4 tahap Lokakarya Pengembangan KTSPT Prodi S1. Pada tahap pertama, dihasilkan naskah akademik; 1) Profil Lulusan, 2) Kompetensi Lulusan, 3) Stabdar Isi, 4) SK dan KD, 5) Struktur Kurikulum, 6) Sebaran Mata Kuliah, dan 7) UKM. Tahap kedua adalah pengembangan silabus yang melibatkan pakar dari IAIN Sunan Ampel (sekarang UIN Surabaya) dan dosen-dosen PTAIS di Tretes. Tahap ketiga adalah perumusan KTSPT prespektif Profesi dengan

\footnotetext{
${ }^{11}$ Menurut data Kelembagaan Diktis Kementerian Agama RI Mei 2014, Saat ini Kopertais IV Surabaya untuk wilayah Jawa Timur, Bali, NTB dan NTT membawahi 154 PTAIS dengan 445 Prodi. Diantara jumlah total tersebut Prodi PAI berjumlah 114 (30,32\%). Lihat: Diktis Kemenag, "Kelembagaan Diktis", http://diktis.kemenag.go.id/rankingptai/tbl_PtkisKopertais.php (diakses pada 7 Oktober 2018)
} 
menghadirkan para pakar, akademisi, praktisi, dan pengguna lulusan. Dan pada tahap terakhir dilakukan revisi dan finishing rumusan dokumen KTSPT ${ }^{12}$.

Sebagaimana diamanatkan dalam Kepmendiknas nomor 232 tahun 2000 tentang penyusunan kurikulum pendidikan tinggi, yang menyatakan bahwa beban studi Prodi PAI sekurang-kurangnya adalah 144 SKS dan sebanyak-banyaknya 160 SKS. Maka dihasilkan Struktur Kurikulum Prodi PAI yang terdiri dari; 1) Mata Kuliah Pengembangan Keperibadian (MPK), 2) Mata Kuliah Penguasaan Keilmuan dan Keterampilan (MKK), 3) Mata Kuliah Keahlian Berkarya (MKB), 4) Mata Kuliah Perilaku Berkarya (MPB), 5) Mata Kuliah Berkehidupan Bermasrakat (MBB), dan 6) Mata Kuliah Keahlian Alternatif (MKKA) ${ }^{13}$.

Tabel 1

Pengelompokan mata kuliah dan jumlah SKS

\begin{tabular}{cccc} 
No. & Kelompok MK & Jumlah MK & Jumlah SKS \\
\hline $\mathbf{1 .}$ & MPK & 14 & 37 \\
\hline $\mathbf{2 .}$ & MKK & 10 & 20 \\
\hline $\mathbf{3 .}$ & MKB & 23 & 61 \\
\hline $\mathbf{4 .}$ & MPB & 3 & 11 \\
\hline $\mathbf{5 .}$ & MBB & 2 & 8 \\
\hline $\mathbf{6 .}$ & MKKA & 5 & 9 \\
\hline Total SKS: & & & 146 \\
\hline
\end{tabular}

Dari total jumlah 146 SKS tersebut pada pengelompokan Mata Kuliah di atas, terdapat 12 SKS Mata Kuliah Bahasa Arab.

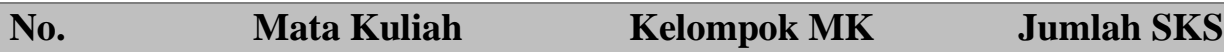

\footnotetext{
12 Tim Penyusun, Kurikulum Tingkat satuan Pendidikan Tinggi, Seri Pengembangan Kurikulum Prodi Pendidikan agama Islam, Cetakan I (Surabaya: Kopertais IV Press, 2009) halaman 2-3.

$13 \mathrm{Ibid}$, halaman 14-16. Tidak berbeda dengan struktur kurikulum dan pengelompokan Mata kuliah dalam Kemendiknas nomor 232/U/2000.Kecuali penambahan kelompok Mata Kuliah Keahlian Alternatif (MKKA).
} 


\begin{tabular}{rccc}
\hline 1. & Bahasa Arab I & MPK & 2 \\
\hline 2. & Bahasa Arab II & MPK & 2 \\
\hline 3. & Bahasa Arab III & MPK & 2 \\
\hline 4. & Bahasa Arab Komunikatif & MKKA & 6 \\
\hline & & Total SKS & 12 SKS \\
\hline
\end{tabular}

Standar Kompetensi (SK) dan Kompetensi Dasar (KD) dari Mata Kuliah Bahasa Arab, secara global dapat dirangkum sebagai berikut ${ }^{14}$ :

a. Bahasa Arab I, II dan III

SK: mampu memahami teks berbahasa arab dengan 1300 kata

KD: terampil memahami teks arab tentang 20 tema; kegiatan sehari-hari, keluarga, cuaca dan musim, silaturrahim, psikologi, pendidikan Islam, kesejahteraan, hari raya Islam, pembukuan hadis, sejarah Islam, pendidikan, HAM, pembukuan Al-Qur'an, kesehatan, sosial, emansipasi wanita, peradaban Islam, komunikasi, kesejahteraan sosial, teknologi informatika, dan perdamaian dunia.

b. Bahasa Arab Komunikatif

SK: Menguasai bahasa arab secara aktif

KD: terampil berkomunikasi dalam bahasa arab pada marhalah mubtadi 'ah, i'dād marhalah mutawassithah, marhalah mutawassithah, i'däd marhalah mutaqaddimah dan marhalah mutaqaddimah.

Untuk menganalisa standar isi dalam SK dan KD di atas, perlu diketengahkan di sini Profil Sarjana S1 Pendidikan Agama Islam sebagai target dari pembelajaran standar isi tersebut dalam suatu struktur kurikulum. Dokumen KTSPT 2009, dengan jelas menyebutkan beberapa kompetensi tambahan selain kompetensi Guru PAI sebagaimana diamanatkan oleh Permendiknas nomor 16 tahun 2007. Kompetensi tambahan ini didasarkan pada hasil analisa terhadap kebutuhan jasa PTAIS, yang

${ }^{14} \mathrm{Ibid}$, halaman 19-23 dan 60-61 
salah satunya adalah (pada poin kedua) bahwa sarjana S1 PAI secara umum harus dapat berbahasa asing. Secara khusus, pada poin d; kemampuan mengembangkan kemampuan professional secara berkelanjutan, ditetapkan target kompetensi menggunakan bahasa inggris untuk mengembangkan wawasan. Dan pada poin $\mathrm{f}$; kemampuan berbahasa asing (Arab dan Inggris), ditetapkan target kompetensi penguasaan bahasa Arab dan sekaligus Inggris secara aktif untuk menunjang penguasaan pembelajaran materi $\mathrm{PAI}^{15}$.

Terlihat menurut standar ini yang terdapat pada SK dan KD Mata Kuliah Bahasa Arab I, II dan III hanya mengakomodasi dua kompetensi bahasa, yaitu kompetensi mendengar (mahārah istimā') dan kompetensi membaca (mahārah qirā'ah) dari empat yang seharusnya dikuasai dalam pembelajaran bahasa, dengan dua yang lain; kompetensi berbicara (mahārah kalām) dan kompetensi menulis (mahārah kitābah). Kecuali memang Mata Kuliah Bahasa Arab Komunikasi adalah Mata kuliah lanjutan dari Mata Kuliah sebelumnya yang mesti harus diambil oleh setiap mahasiswa, dan bukan merupakan Mata Kuliah pilihan sebagaimana konsep dalam MKKA. Sebab jika mahasiswa memilih Bahasa Inggris - dan bukan bahasa Arab maka ini berarti kompetensi berbicara (mahärah kalām) dan kompetensi menulis (mahārah kitābah) sama sekali tidak terakomodir. Dalam hal pengembangan keilmuan - sebagaimana dimanatkan dalam profil lulusan - kompetensi menulis (mahārah kitābah, writing skill) adalah sebuah keniscayaan yang wajib dimiliki. Untuk keperluan ini, terdapat dua kompetensi sekaligus yang harus dikuasai; kompetensi reseptif dan juga kompetensi reproduktif. Reseptif adalah kemampuan untuk mendapatkan bahan-bahan kognitif sebanyak mungkin. Kemampuan ini menuntut seseorang untuk banyak membaca dan membaca, tidak peduli apakah bahan bacaan itu merupakan bahan kajian pada bidangnya atau diluar kajian bidangnya sama sekali, sebab sekarang ini dunia telah berada pada zaman persinggungan ilmu (integrasi interkonektif). Sementara kompetensi reproduktif adalah kemampuan untuk mengembangkan bahan-bahan kognitif itu dengan melakukan reinterpretasi, analisa mendalam dan luas, penelitian-penelitian dan

\footnotetext{
${ }^{15}$ Ibid, halaman 5-7
} 
kajian-kajian, untuk kemudian dapat menghasilkan sebuah temuan baru sebagai produksi kembali ilmu yang lebih baru. ${ }^{16}$ Oleh karena itu, perlu adanya pengelompokan yang proporsional mengenai kompetensi-kompetensi kebahasaan kedalam dua ranah yang jelas; pertama, kompetensi mendengar (mahārah istimā') dan kompetensi membaca (mahārah qirā'ah) sebagai kompetensi reseptif (mahärah istiqbāl), dan kedua, kompetensi berbicara (mahārah kalām) dan kompetensi menulis (mahārah kitābah) sebagai kompetensi reproduktif (mahārah intāj). ${ }^{17}$ Dari kedua kompetensi ini, kompetensi membaca teks (mahärah qirā'ah) adalah kompetensi yang menjadi tekanan dalam kompetensi reseptif, dan kompetensi menulis teks (mahārah kitābah) dalam kompetensi reproduktif.

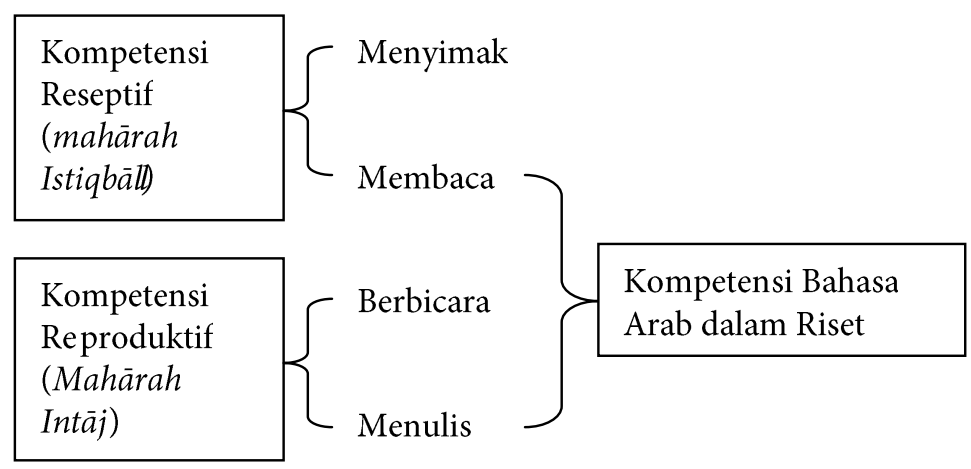

Gambar 1

Kompetensi Bahasa Arab

Sementara pengelompokan Mata Kuliah dalam Struktur KTSPT tahun 2009 sebagaimana ulasan di atas, menurut penulis perlu dikaji ulang sebab kurang memperhatikan unsur proporsionalitas guna pencapaian kompetensi yang diamanatkan oleh Kepmendiknas nomor 045/U/2002, yaitu; 1) landasan kepribadian, 2) penguasaan ilmu dan keterampilan, 3) kemampuan berkarya, 4) sikap dan perilaku dalam berkarya menurut tingkat keahlian berdasarkan ilmu dan keterampilan yang

\footnotetext{
16 Abdurrahman, "Writing Skill Dosen Menuju Research University Berbasis Pesantren", Paper, disajikan dalam Diskusi PKBB LP3M STAI Al-Qolam di Ganjaran Gondanglegi Malang (1 Desember 2013).

${ }^{17}$ Abdurrahman Ibrahim al-Fauzan, Idlā'ah li raf' Kafā'ah Mu'allimì al-Lughah al-'Arabiyah li Ghair alNāthiqīn bihā, cetakan I (Riyad: al-Humaydli, 2011) halaman 176
} 
dikuasai, 5) pemahaman kaidah berkehidupan bermasyarakat sesuai dengan pilihan keahlian dalam berkarya. Artinya pengelompokan Mata Kuliah menjadi tidak berperan lagi, sebab tidak terkait langsung dengan pencapaian kompetensi lulusan. Bisa terjadi satu Mata Kuliah dibangun untuk mencapai satu atau lebih kompetensi (learning to do, learning to know, learning tobe, learning to live together), dan sebaliknya satu kompetensi dapat dicapai lewat lebih dari satu Mata Kuliah, sehingga pengelompokan Mata Kuliah menjadi sulit dilakukan atau dapat dikatakan tidak bisa dilakukan, kecuali dipaksakan. Pencapaian kompetensi menjadi tujuan/sasaran kurikulum, bukan pengelompokan Mata Kuliah ${ }^{18}$.

\section{PEMBELAJARAN BAHASA ARAB KOMUNIKATIF (PBAK)}

Kata "komunikatif" dalam PBAK sebenarnya tidak menunjuk pada pengertian kompetensi, namun justru harus dipahami sebagai pendekatan (approach, madkhal ittishāli $)$. Pendekatan Komunikatif dalam pembelajaran bahasa adalah model mutakhir yang sangat populer, karena dinilai integral dan memiliki karakteristik yang pasti, serta bertujuan pada pencapaian kemampuan komunikasi yang aktif dan praktis ${ }^{19}$. Yang terakhir ini menunjukkan bahwa "kompetensi komunikatif" adalah salah satu tujuan dari pendekatan PBAK. Dua tujuan yang lain adalah kompetensi kebahasaan dan kebudayaan.1) Kompetensi komunikatif adalah kemampuan berekspresi dengan bahasa target dan dapat diterima dengan baik oleh penutur asli, 2) kompetensi kebahasaan merupakan kemahiran kognisi kebahasaan, mulai dari suara sampai gramer, dan 3) kompetensi kebudayaan adalah performance yang sesuai dengan budaya bahasa target. Ketiga kompetensi ini harus secara bersamaan dihadirkan dalam pembelajaran di setiap tingkat, mulai dari tingkat elementary sampai advance $e^{20}$.

\footnotetext{
18 Tim Penyusun, Buku Panduan Pengembangan Kurikulum Berbasis Kompetensi Pendidikan Tinggi (Sebuah Alternatif Penyusunan Kurikulum), (Jakarta: Dirjen Dikti, 2008) halaman 12

19 Zaenuddin et.al, Metodologi dan Strategi Alternatif Pembelajaran Bahasa Arab.(Yogyakarta: Pustaka Rihlah Group, 2005), halaman 36.

${ }^{20}$ Abdurrahman Ibrahim, Idlä'atu, halaman 140
} 
Menilik sejarahnya, pendekatan ini lahir dari kegagalan pengembangan beberapa metode pendahulunya yang masih populer sampai tahun 60-an, antara lain;1) metode Situational Language Teaching yang dikecam karena berakibat dikotomi antara competence dan performance ${ }^{21}, 2$ ) metode audio-lingual yang harus menghadirkan native-speaker dan penyediaan media yang mahal, dinilai gagal meningkatkan kompetensi komunikasi peserta didik ${ }^{22}$.

Pendekatan PBAK dilandasi asumsi bahwa; 1) setiap individu memiliki kemampuan pemerolehan bahasa sejak lahir (jihāz iktisāb al-lughah/language acquisition device, $L A D)$, sehingga kompetensi bahasa bersifat kreatif dan lebih dipengaruhi faktor internal ini, dan 2) kemahiran bahasa tidak hanya terbatas hanya pada empat skill bahasa saja (istimà', qirä'ah, kalām dan kitābah), namun mencakup segala keterampilan komunikasi yang luas, sesuai dengan peran, situasi dan tujuan interaksi ${ }^{23}$.Yang terakhir ini menegaskan bahwa pembelajaran bahasa asing (bahasa kedua) dalam pendekatan PBAK tidak mengharuskan target pencapaian seluruh kemahiran bahasa (mahārāt lughawiyah), justru harus dibatasi dan disesuaikan dengan kebutuhan peserta didik.Sebagai ilustrasi, UIN Maliki Malang sejak 2012 mulai menerapkan pendekatan PBAK berdasarkan asumsi kedua, dengan menerbitkan Buku Seri Pembelajaran Bahasa Arab untuk Tujuan Khusus (salāsil al-'arabiyah li aghrādl khāshah) ${ }^{24}$.

Oleh karena itu, makalah ini mengikuti asumsi kedua, dimana pengertian pendekatan PBAK dimaksudkan sebagai pendekatan pengembangan kurikulum Bahasa Asing (termasuk Bahasa Arab). Muhaimin (dalam Dhiauddin, 2015) merumuskan beberapa pendekatan yang dapat digunakan dalam pengembangan kurikulum, yaitu: pendekatan subjek akademis, pendekatan humanistis, pendekatan teknologis, dan pendekatan reknstruksi sosial. Pada pendekatan teknologis,

21 Furqanul Azis dan Ghaedar al-Wasilah, Pengajaran Bahasa Komunikatif: Teori dan Praktek,(Bandung: Remaja Rosdakarya, 1996), halaman 1

$22 \mathrm{H}$. Douglas Brown, Principles of Language Learning and Teaching, cetakanX (Amerika: Prentice Hall, 1987), halaman 213

${ }^{23}$ Ahmad Fuad Effendy, Metodologi Pengajaran Bahasa Arab, (Malang: Misykat, 2005), halaman 52.

${ }^{24}$ Imam Suprayogo, Kata Pengantar dalam Aunul Hakim, et.al, al-'Arabiyah li Aghrādlin Khāshah, (Malang: PKPBA, 2012) halaman d 
Muhaimin menekankan bahwa pengembangan harus bertolak dari analisis kompetensi untuk melaksanakan tugas-tugas atau pekerjaan tertentu (job analysis). ${ }^{25}$

\section{SOLUSI KONSTRUKSI PBAK KBK KKNI}

Pada dasarnya, KKNI diawali oleh kegelisahan akademisi terhadap output lembaga pendidikan yang cenderung kurang memenuhi permintaan pengguna lulusan dalam dunia industri, yaitu berupa tenaga kerja dengan seperangkat skill dan kompetensi yang sesuai dengan pasar $^{26}$. Artinya dalam setiap profesi mengharuskan adanya ketentuan kualifikasi yang jelas, sehingga dapat dipertanggung jawabkan kompetensi yang mestinya dimiliki oleh seseorang yang berprofesi tertentu dan kemudian dapat ditentukan penghargaan terhadap profesi tersebut secara professional dan proporsional.

Penerapan KKNI dalam membangun struktur kurikulum PTAIS diharapkan dapat memperjelas penataan jenis dan jenjang pendidikan PTAIS ke depan, yang pada ujungnya akan berimplikasi pada penyetaraan SDM lulusan PTAIS, sehingga kualifikasi kompetensi yang dimiliki sesuai dan sinergi dengan profesi yang akan disandangnya di tengah masyarakat, dan dimungkinkan adanya usaha pengembangan sistem penjaminan mutu bagi profesi Pendidik Agama Islam di Indonesia. Disamping itu, KKNI merupakan fasilitasi konstruksi pendidikan sepanjang hayat (uthlubū al-'ilm min al-mahd ilā al-lahd, long life education) ${ }^{27}$

\footnotetext{
${ }^{25}$ Dhiauddin, Model-model dan pendekatan dalam pengembangan kurikulum Bahasa Arab, Makalah, (Disampaikan pada Kuliah Doktor Pendidikan Bahasa Arab di Pascasarjana UIN Maliki Malang pada tanggal 15 Mei 2015), halaman 12 dan 16.

${ }^{26}$ Pada awalnya KKNI disusun oleh Kementerian Tenaga Kerja dan Transmigrasi sejak tahun 2003, sebelum kemudian dilimpahkan kepada Kemdikbud dalam satu tim khusus pimpinan Megawati Santoso. Lihat: Kampusiana, "KKNI", http://kelembagaan.ristekdikti.go.id/index.php/2016/05/02/kkni-pastikan-kualitas-lulusanperguruan-tinggi/ (diakses pada 7 Oktober 2018)

27 Hendrawan Soetanto, Kurikulum Berbasis Kompetensi dalam kaitannya dengan KKNI, Slide Presentasi, disajikan pada Lokakarya Pengembangan Kurikulum PTAIS KOPERTAIS IV Surabaya, tanggal 11 November 2013 (Sidoarjo: Hotel Utami, 2013) hal. 31
} 
Merujuk pada lampiran KKNI yang memuat Deskripsi Jenjang Kualifikasi KKNI, terdapat dua jenis kualifikasi yang dapat dipetakan penempatan jenjangnya; 1) deskripsi umum, yaitu kualifikasi yang wajib tetap dipenuhi dalam setiap jenjang, dan 2) deskripsi khusus, yang dipetakan dalam sembilan jenjang. Berikut gambaran pemetaan kualifikasi sesuai empat fenomena kompetensi;

Tabel 3

Pemetaan kualifikasi berdasarkan kompetensi

\begin{tabular}{cccccc} 
& Anthropos & Tekne & Oikos & Etnos & \\
\cline { 1 - 5 } Deskripsi Umum & $\sqrt{ }$ & - & $\sqrt{ }$ & $\sqrt{ }$ & Soft Skill \\
\hline $\mathbf{1}$ & - & $\sqrt{ }$ & - & $\sqrt{ }$ & Hard Skill \\
\hline $\mathbf{2}$ & - & $\sqrt{ }$ & - & $\sqrt{ }$ & \\
\hline $\mathbf{3}$ & - & $\sqrt{ }$ & $\sqrt{ }$ & $\sqrt{ }$ & \\
\hline $\mathbf{4}$ & - & $\sqrt{ }$ & $\sqrt{ }$ & $\sqrt{ }$ \\
\hline $\mathbf{5}$ & - & $\sqrt{ }$ & $\sqrt{ }$ & $\sqrt{ }$ \\
\hline $\mathbf{6}$ & - & $\sqrt{ }$ & $\sqrt{ }$ & $\sqrt{ }$ \\
\hline $\mathbf{7}$ & - & $\sqrt{ }$ & $\sqrt{ }$ & $\sqrt{ }$ \\
\hline $\mathbf{8}$ & - & $\sqrt{ }$ & $\sqrt{ }$ & $\sqrt{ }$ \\
\hline $\mathbf{9}$ & - & $\sqrt{ }$ & $\sqrt{ }$ & $\sqrt{ }$
\end{tabular}

a. deskripsi umum mencakup; beriman dan bertaqwa terhadap Allah Swt dan berakhlak mulia, dan berkepribadian yang baik dalam melaksanakan tugasnya (anthropos), cinta tanah air, berperan, mampu bekerja sama, peduli, dan menghargai orang lain (oikos), dan taat hukum serta mendahulukan kepentingan bangsa dan masyarakat (etnos).

b. deskripsi khusus mencakup; memiliki pengetahuan faktual dan operasional, sehingga mampu melaksanakan tugas, menguasai prinsip dan konsep teoritis bidang tertentu, sehingga mampu mengaplikasikan bidang keahliannya, mampu memecahkan permasalahan keilmuan monodisipliner, kemudian multidisipliner dan transdisipliner, sehingga mampu merencanakan dan mengelolan sumber daya, dan mengembangkan 
pengetahuan dan teknologi (tekne), mampu bekerja sama, berkomunikasi, dan menulis laporan dengan baik (oikos), dan bertanggung jawab atas pekerjaan sendiri, kemudian pekerjaan orang lain, dan mengambil keputusan dengan tepat (etnos).

Kenapa KBK? Pertanyaan yang pasti muncul, sebab setelah KBK, setidaknya sudah ada dua model pengembangan kurikulum yang digunakan secara nasional di negeri ini; KTSP tahun 2006 dan Kurikulum 2013. KBK merupakan revoluasi orientasi pembelajaran dalam bentuk regulasi bangunan kurikulum, dari kurikulum konvensional tahun 1994 atau disebut Kurikulum Berbasis Isi (KBI) sesuai Kepmendikbud nomor 056/U/1994 yang masih teacher centered learning (TCL), menjadi Kurikulum Berbasis Kompetensi (KBK) tahun 2000 menurut Kepmendiknas nomor 232/U/2000 yang berubah $180^{\circ}$ ke student centered learning $(\mathrm{SCL})^{28}$.

\begin{tabular}{|c|c|c|c|}
\hline No. & Tinjauan & KBI & KBK \\
\hline 1. & Outcome & $\begin{array}{l}\text { Kemampuan minimal } \\
\text { sesuai sasaran kurikulum }\end{array}$ & $\begin{array}{l}\text { Kompetensi yang dianggap } \\
\text { mampu oleh masyarakat }\end{array}$ \\
\hline 2. & $\begin{array}{l}\text { Penilaian kuali- } \\
\text { tas lulusan }\end{array}$ & Perguruan Tinggi sendiri & $\begin{array}{l}\text { Perguruan Tinggi dan Stake- } \\
\text { holders }\end{array}$ \\
\hline 3. & Penekanan & $\begin{array}{l}\text { Output; lebih banyak } \\
\text { menekankan hard skill }\end{array}$ & $\begin{array}{l}\text { Outcome: } \quad \text { keseimbangan } \\
\text { hard skill dan soft skill }\end{array}$ \\
\hline 4. & Pembelajaran & $\begin{array}{l}\text { TCL, Transfer of } \\
\text { Knowledge }\end{array}$ & $\begin{array}{l}\text { SCL, method of inquiry and } \\
\text { discovery }\end{array}$ \\
\hline
\end{tabular}

Sementara kurikulum setelahnya merupakan pengembangan dan penyempurnaan dari KBK. KTSP tahun 2006, adalah model konstruksi kurikulum secara komprehensip dari akar stakeholder dengan penyusunan Rencana Kerja dan Anggaran (RKA) sehingga mencirikan tingkat satuan pendidikan, namun tetap bertumpu dan

${ }^{28}$ Tim Penyusun, Buku Panduan, halaman 10 
mengacu pada standar kompetensi yang ada pada Standar Isi (SI) dan Standar Kompetensi Lulusan (SKL) ${ }^{29}$. Dan Kurikulum 2013 adalah pengembangan KTSP melalui Permendikbud Nomor 81A tahun 2013 yang memuat pedoman penyusunan dan pengelolaan KTSP dalam salah satu dari lima lampirannya. Menilik hal ini, maka penggunaan KBK menjadi solusi yang ditawarkan tulisan ini untuk menjadi instrumen metode rekonstruksi kurikulum PTAIS yang kemudian mengacu pada KKNI sebagai solusi instrument penentuan kualifikasi kompetensi profesi lulusan PTAIS nantinya. Lebih dari itu, menurut Prof. Hendrawan, kekuatan KBK KKNI adalah jika dihadapkan pada empat fenomena kompetensi yang wajib dimiliki oleh SDM lulusan dalam profilnya, yaitu terwujudnya; 1) manusia ImTaq (fenomena anthropos), 2) menguasai IpTek (fenomena tekne), 3) hidup harmonis bersama masyarakat (fenomena oikos), dan 4) berperilaku sesuai dengan norma (fenomena etnos $)^{30}$.

Perlu diperhatikan dan ditekankan kembali di sini, bahwa penggunaan model KBK yang mengacu pada KKNI dalam rekonstruksi bangunan kurikulum di PTAIS masih baru gagasan, atau hanya sekedar instrumen yang akan mewujudkan struktur bangunan kurikulum otonom yang dapat diakui dan disandingkan kualifikasinya dengan profesi yang menjadi kebutuhan masyarakat saat ini dan masa-masa mendatang. Sebab sampai tulisan ini berlangsung, belum ada perangkat regulasi penerapan KBK KKNI yang diterbitkan oleh Kemenag $\mathrm{RI}^{31}$. Dengan demikian, rancangan dalam tulisan ini dapat menjadi usulan dan rekomendasi bagi instansi terkait (dalam hal ini Kopertais dan Diktis Kemenag RI) dalam kerja rekonstruksi kurikulum PTAIS.Disamping itu, tulisan ini dapat diproyeksikan nantinya guna

\footnotetext{
${ }^{29}$ KTSP lahir seiring dengan UU Sisdiknas nomor 20 tahun 2003 dan PP nomor 19 tahun 2005 tentang Standar Nasional Pendidikan. Sementara SI dan SKL ditetapkan berdasarkan regulasi kementerian terkait, dan untuk Pendidikan Tinggi ditetapkan melalui Kepmendiknas nomor 045/U/2002 tentang kurikulum inti pendidikan tinggi.

${ }^{30}$ Hendrawan, Kurikulum Berbasis Kompetensi, hal. 6

${ }^{31} \mathrm{KKNI}, \mathrm{Bab}$ III, Pasal 9 ayat (3) berbunyi: Ketentuan lebih lanjut mengenai penerapan KKNI diatur oleh Menteri yang membidangi ketenagakerjaan dan meteri yang membidangi pendidikan baik secara bersama-sama atau sendiri-sendiri sesuai bidang tugasnya masing-masing. Peraturan Presiden Republik Indonesia nomor 8 tahun 2012 tentang Kerangka Kualifikasi Nasional Indonesia. Lembaran Negara Republik Indonesia nomor 24 tahun 2012.
} 
menjadi salah satu rujukan rumusan regulasi teknis penerapan $\mathrm{KKNI}$, khususnya untuk rumusan kurikulum Pembelajaran Bahasa Arab Komunikatif di PTAIS.

Merujuk pada Peraturan Presiden nomor 8 tahun 2012 tentang Kerangka Kualifikasi Nasional Indonesia (KKNI) BAB II Pasal 5, bahwa capaian pembelajaran lulusan S1 paling rendah setara dengan jenjang kualifikasi $6^{32}$. Dan menurut jenjang tersebut dapat digambarkan deskripsi kualifikasi kompetensi Bahasa Asing untuk lulusan S1 Prodi PAI sebagai berikut:

a. Menguasai konsep teoritis bahasa asing secara umum dan mendalam

b. Mampu mengaplikasikan bahasa asing untuk memanfaatkan ilmu pengetahuan, teknologi pada bidang PAI

c. Mampu menafsirkan dan menganalisa data berbahasa asing, untuk mendapatkan petunjuk dan solusi secara mandiri atau kelompok.

Penerjemahan deskripsi di atas dalam kontruksi KBK KKNI harus didasarkan pada usaha mensepadankan konsep UNESCO dengan persyaratan profesi versi DIKTI, sebab keduanya menjadi dasar pijakan kontruksi KBK. UNESCO mengamanatkan empat pilar pendidikan tinggi; 1) learning to know, 2) learning to do, 3) learning to be, dan 4) learning to live together. Sementara hasil survei DIKTI terhadap persyaratan umum profesi adalah kemampuan; 1) analisis dan sintesis, 2) menguasai IT, 3) managed ambiguity, 4) communication, dan 5) bahasa asing ${ }^{33}$.

\footnotetext{
32 Deskripsi Jenjang Kualifikasi tingkat 6 berbunyi: 1) mampu mengaplikasikan bidang keahliannya dan memanfaatkan ilmu pengetahuan dan teknologi dan/atau seni pada bidangnya dalam penyelesaian masalah serta mampu beradaptasi terhadap situasi yang dihadapi, 2) menguasai konsep teoritis bidang pengetahuan tertentu secara umum dan konsep teoritis bidang khusus dalam bidang pengetahuan tersebut secara mendalam, serta mampu memformulasikan penyelesaian masalah prosedural, 3) mampu menyelesaikan masalah denga tepat berdasarkan analisis informasi dan data, dan mampu memberikan petunjuk dalam memberikan berbagai alternatif solusi secara mandiri dan kelompok, 4) bertanggung jawab pada pekerjaan sendiri dan dapat diberi tanggung jawab atas pencapaian hasil kerja organisasi. Lihat: Ibid.

${ }^{33}$ Tim Penyusun, Buku Panduan, halaman 11. Empat pilar pendidikan pertama dan kedua merupakan penguasaan kompetensi dari pada penguasaan ketrampilan menurut klasifikasi ISCE (International Standard Classification of Education).Sedangkan pilar ketiga dan keempat adalah dematerialisasi pekerjaan dan kemampuan berperan menurut standar ISCO (International Standard Classification of Occupation). Lihat ibid. halaman 1.
} 


\section{UNESCO KBK KKNI}

\section{Pembelajaran learning to know,}

Bahasa Arab learning to do, Komunikatif learning to be, (PBAK) and learning to live together
1. Menguasai konsep teoritis bahasa asing secara umum dan mendalam

2. Mampu mengaplikasikan bahasa asing untuk memanfaatkan ilmu pengetahuan, teknologi pada bidang PAI

3. Mampu menafsirkan dan menganalisa data berbahasa asing, untuk mendapatkan petunjuk dan solusi secara mandiri atau kelompok.

Sehingga secara praktis, Pembelajaran Bahasa Arab Komunikatif (PBAK) sejatinya tidak boleh terkotak pada salah satu dari empat kelompok Mata Kuliah, sebab kompetensi bahasa asing mahasiswa tidak boleh berhenti hanya pada to know atau paling banter to do. Sebagaimana amanat Kepmendiknas nomor 045/U/2002, Konsep KBK KNNI mencanangkan PBAK berbentuk Mata Kuliah yang terintegrasi dengan lima kompetensi sekaligus; 1) landasan kepribadian, 2) penguasaan ilmu dan keterampilan, 3) kemampuan berkarya, 4) sikap dan perilaku dalam berkarya menurut tingkat keahlian berdasarkan ilmu dan keterampilan yang dikuasai, 5) pemahaman kaidah berkehidupan bermasyarakat sesuai dengan pilihan keahlian dalam berkarya. Artinya secara sinergi dan terintegrasi, satu atau beberapa Mata Kuliah PBAK dibangun untuk mencapai satu atau lebih kompetensi (learning to do, learning to know, learning tobe, learning to live together).

Lalu kenapa harus dimulai dari kurikulum?.Ini juga pertanyaan urgen yang harus penulis jelaskan, tidak perlu panjang lebar dalam makalah ini. Menurut penulis, peningkatan mutu lembaga pendidikan, linier dengan peningkatan kualitas SDM lulusannya, jika profil lulusan PTAIS sesuai dengan kualifikasi dan kompetensi yang dibutuhkan oleh masyarakat atau pengguna lulusan, maka sudah tentu mutu PTAIS akan meningkat dengan sendirinya. Dititik inilah kenapa pengembangan lembaga 
Madin harus dimulai dari rekonstruksi kurikulum, di mana makalah ini merekomendasikan untuk menggunakan KBK KKNI sebagai instrumen paling tepat. Walaupun ada yang berpendapat bahwa kualitas SDM lulusan tidak tergantung sepenuhnya pada model kurikulum. Penulis sependapat dengan pandangan ini, namun bukan berarti tidak melakukan apa-apa dan hanya menunggu hasil yang baik, bukan? Oleh karenanya perlu diperhatikan bahwa pengembangan lembaga (institusional development) yang dimaksudkan dalam makalah ini seperti terlihat dalam gambar;

\begin{tabular}{|c|c|}
\hline Student development & Institutional development \\
\hline \multirow[t]{5}{*}{ Profil lulusan } & \\
\hline & $\downarrow$ \\
\hline & $\begin{array}{c}\text { Cita-cita lembaga } \\
\qquad\end{array}$ \\
\hline & $\begin{array}{c}\text { Visi, Msi dan Tujuan } \\
\downarrow\end{array}$ \\
\hline & Program kerja \\
\hline \multicolumn{2}{|c|}{ Konstruksi Kurikulum $\longleftarrow$} \\
\hline
\end{tabular}

Gambar 2

Pengembangan lembaga

Sebagai ilustrasi riil, Visi besar yang ingin dicapai pada STAI Al-Qolam Gondanglegi Malang adalah; "Menjadi Universitas Islam Riset berbasis Pesantren terbaik se Jawa Timur pada tahun 2020". Rumusan visi ini adalah hasil diskusi dan dialog panjang, yang bahkan dibawa ke kancah Internasional pada Annual International Conference on Islamic Studies (AICIS) ke-14, di Balikpapan pada tanggal 21 - 24 November 2014 baru-baru ini oleh salah satu Dosen. Salah satu titik tekan pada Visi besar ini adalah model perguruan tinggi riset yang mengharuskan tidak hanya Dosen, na mun juga mahasiswa untuk menjadi "Mahasiswa yang selalu meneliti". Hal ini yang akan membawa Misi, Tujuan dan Program kerja - termasuk dalam pembelajaran Bahasa Arab - di STAI Al-Qolam menuju pada cita-cita tersebut. Maka 
dalam rumusan kurikulum PBAK STAI Al-Qolam, diharapkan dapat merespon arahan program ini - yang dalam makalah ini diusulkan - dengan bangunan kurikulum KBK KKNI.

Guna merealisasikan keperluan ini, menurut penulis, salah satu yang dapat dilakukan adalah adanya terobosan baru dalam PBAK di PTAIS, yakni dengan membangun sebuah lembaga pembelajaran bahasa asing kominikatif di luar Fakultas/Prodi. Sebut saja sebagai ilustrasi, lembaga tersebut adalah Pusat Bahasa (Language Center/LC) yang banyak dimiliki oleh PTAIS, dengan berbagai sebutan dan nama. Optimalisasi LC dapat dimulai dari dua hal; 1) reformasi tugas dan fungsi LC, tidak hanya sebagai pusat kajian, atau pusat pembelajarn ekstra kurikuler semata, namun lebih dari itu, LC diberikan limpahan PBAK intra kurikuler yang bersinergi dan terintegrasi dengan lima sasaran kompetensi lulusan yang ada di Fakultas/Prodi, 2) melimpahkan PBAK dari Fakultas/Prodi kepada LC. Artinya PBAK tidak lagi ditangai oleh Fakultas/Prodi, namun difakuskan pada LC. Pelimpahan ini tidak semata-mata pemindahan mata kuliah, namun harus melewati proses "konversi kurikulum" sesuai standar kompetensi tertentu, menurut rumusan konstruksi KBK KKNI masing-masing PTAIS.

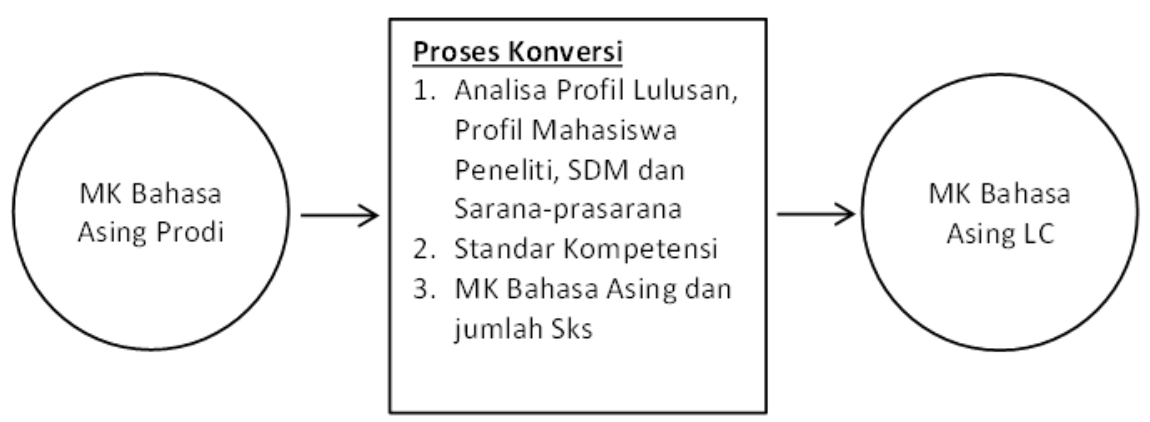

Gambar 3

\section{PENUTUP}


Kurikulum sesungguhnya tidak hanya sekedar dilihat dari dokumen dan bagaimana struktur kurikulum di dalamnya, namun perlu diikuti dengan pembelajarannya. Perubahan kurikulum berarti juga perubahan pembelajaran terutama perubahan perilaku dan pola pikir dari peserta serta pelaku pembelajarannya, agar indikator kebehasilan (outcome) pembelajaran yang ditetapkan dapat benar-benar tercapai. Sebab Kurikulum Pendidikan Tinggi adalah seperangkat rencana dan pengaturan mengenai isi maupun bahan kajian serta cara penyampaian dan penilaian. Oleh karena itu, Kurikulum Tingkat Satuan Pendidikan Tinggi (KTSPT) tahun 2009 yang bermasalah secara struktural, karena terkotak dalam pengelompokan mata kuliah, dan tidak berorientasi pada pencapaian kompetensi lulusan, tentu sudah pasti berakibat sistemik pada proses pembelajarannya pada setiap PTAIS yang menggunakannya.

Untuk menyelesaikan masalah ini, khususnya pada Pembelajaran Bahasa Arab Komunikatif (PBAK), tulisan ini menawarkan solusi berupa rekonstruksi Kurikulum PTAIS kedepan dengan KBK KKNI menurut Peraturan Presiden RI nomor 8 tahun 2012, dan meletakkan PBAK sebagai suatu pendekatan pembelajaran (communication approach). Dimana Kerangka Kualifikasi Nasional Indonesia (KKNI)menempatkan kompetensi lulusan S1 pada jenjang 6, dan Kurikulum Berbasis Kompetensi (KBK) mensyaratkan pembentukan struktur kurikulum yang mengarah pada lima kompetensi sesuai dengan empat pilar pendidikan (learning to do, learning to know, learning tobe, dan learning to live together), yang bermakna pada penguasaan kompetensi dari pada penguasaan ketrampilan menurut klasifikasi ISCE (International Standard Classification of Education) dan ISCO (International Standard Classification of Occupation), dematerialisasi pekerjaan dan kemampuan berperan.

Untuk mencapai cita-cita ini, pula tulisan ini menawarkan salah satu terobosan berupa optimalisasi Pusat Bahasa (Leanguage Center/LC) yang ada di PTAIS, dengan dua langkah; 1) reformasi tugas pokok dan fungsi LC yang hanya melayani 
pembelajaran ekstra kurikuler, menjadi lembaga resmi yang mengadakan PBAK intra kurikuler, dan 2) pelimpahan PBAK dari Fakultas/Prodi ke LC melalui proses konversi kurikulum.

Wallāhu a'lam bi al-Shawāb. [] 


\section{REFERENCES}

2018 Asian University Ranking, “2018 Asian University Ranking”, https://www.4icu.org/top-universities-asia/ (diakses pada 7 Oktober 2018).

Abdurrahman, "Writing Skill Dosen Menuju Research University Berbasis Pesantren", Paper, disajikan dalam Diskusi PKBB LP3M STAI Al-Qolam di Ganjaran Gondanglegi Malang (1 Desember 2013).

Brown, H. Douglas. (1987). Principles of Language Learning and Teaching, cetakan $\mathrm{X}$, Amerika: Prentice Hall

Center for World -Class Universitas Shanghai Jiao Tong University, "Academic Ranking of World Universities 2018", http://www.shanghairanking.com/ARWU2018.html, (diakses pada 7 Oktober 2018)

Dhiauddin, Model-model dan pendekatan dalam pengembangan kurikulum Bahasa Arab, Makalah, (Disampaikan pada Kuliah Doktor Pendidikan Bahasa Arab di Pascasarjana UIN Maliki Malang pada tanggal 15 Mei 2015)

Diktis Kemenag, "Kelembagaan Diktis", http://diktis.kemenag.go.id/rankingptai/tbl_PtkisKopertais.php (diakses pada 7 Oktober 2018)

Effendy, Ahmad Fuad. (2005). Metodologi Pengajaran Bahasa Arab, Malang: Misykat

al-Fauzan, Abdurrahman Ibrahim. (2011). Idlä'atu lirafi Kafä'ati Mu'allimī alLughati al-'Arabiyah lighayri al-Nātiqīna bihā, cetakan I, Riyad: al-Humaydli

Kromosudiro, Fauzi, “Konsep Dasar KKNI”, www.fauziep.com/konsep-dasar-kkni/ (diakses pada 7 Oktober 2018)

Kurikulum PTAIS KOPERTAIS IV Surabaya, tanggal 11 November 2013 Sidoarjo: Hotel Utami, 2013

Kampusiana, "KKNI”, $\quad$ http://kelembagaan.ristekdikti.go.id/index.php12016/05/02/kkni-pastikan-kualitas-lulusan-perguruan-tinggi/ (diakses pada 7 Oktober 2018) 
Muhid, Abdul. (2013). Hasil Lokakarya Kurikulum KBK berbasis KKNI Kopertais IV Surabaya Tahun 2013, Notulensi, Surabaya: Tim Pengembang Kopertais IV

Peraturan Menteri Pendidikan dan Kebudayaan RI nomor 81 tahun 2014, ditetapkan pada tanggal 20 Agustus 2014 oleh Muhammad Nuh.

Peraturan Presiden Republik Indonesia nomor 8 tahun 2012 tentang Kerangka Kualifikasi Nasional Indonesia.Lembaran Negara Republik Indonesia nomor 24 tahun 2012.

Rahardjo, Mudjia. 2013). Tantangan Sarjana PTAI menyongsong Priode Respiritualisasi Global, Orasi Ilmiah, disampaikan pada Rapat Senat Terbuka Wisuda TA. 2013/2014 STAI Al-Qolam Gondanglegi, tanggal 7 Desember 2013 (Gondanglegi: STAI Al-Qolam, 2013)

Soetanto, Hendrawan. (2013). Kurikulum Berbasis Kompetensi dalam kaitannya dengan KKNI, Slide Presentasi, disajikan pada Lokakarya Pengembangan Suprayogo, Imam. (2012). "Kata Pengantar" dalam Aunul Hakim, et.al, al'Arabiyah li Aghrādlin Khāshah, Malang: PKPBA

The Times Higher Education World University Rankings, "Asia University Ranking 2018”, https://www.timeshighereducation.com/world-university-rankings/2018/regional-ranking. (diakses pada 7 Oktober 2018)

Tim Penyusun, (2008). Buku Panduan Pengembangan Kurikulum Berbasis Kompetensi Pendidikan Tinggi (Sebuah Alternatif Penyusunan Kurikulum), Jakarta: Dirjen Dikti

Tim Penyusun, (2009). Kurikulum Tingkat satuan Pendidikan Tinggi, Seri Pengembangan Kurikulum Prodi Pendidikan agama Islam, Cetakan I, Surabaya: Kopertais IV Press

al-Wasilah, Furqanul Azis dan Ghaedar. (1996). Pengajaran Bahasa Komunikatif: Teori dan Praktek, Bandung: Remaja Rosdakarya

Webometrics, “About Us”, http://www.webometrics.info/en/About Us, (diakses pada 7 Oktober 2018) 
Zaenuddin et.al, (2005). Metodologi dan Strategi Alternatif Pembelajaran Bahasa Arab. Yogyakarta: Pustaka Rihlah Group 